\title{
Problems and Countermeasures of Cooperative Learning in Business English
}

\author{
Juan $\mathrm{Gu}$ \\ Sichuan University of Arts and Science, Dazhou, China
}

\begin{abstract}
Cooperative learning focuses on group activities, emphasizing student activity as the center, teachers as organizers, instructors, supervisors, and evaluators. As an effective teaching model, cooperative learning is increasingly adopted in Business English teaching that needs a lot of student activities and practices. However, cooperative learning still has various problems in the process of Business English teaching, so this paper aims to analyze the problems in classroom setting, group formation, teachers, students and teaching assessment, and eventually propose countermeasures to solve these problems.
\end{abstract}

Index Terms - cooperative learning, Business English, classroom setting, group formation, assessment

\section{INTRODUCTION}

Business English, as an independent undergraduate major, was approved by the Ministry of Education of China in 2008 with unremitting efforts made by numerous Chinese Business English people. In the year of 2014, Business English major was accessible at 216 colleges and universities. By 2019, a total of 943 colleges and universities across the country have opened this major.

Due to its special nature, the Business English major requires students to not only have the integrated abilities to use languages, such as listening, speaking, reading, writing, translating, etc., but also learn business professional knowledge and some basic practical English skills in intercultural communication (Zhu,2010,pp.23-27). Furthermore, because Business English is a very practical subject, cooperative learning has become the first teaching model for Business English teachers to organize classroom teaching. Various studies and experiments at home and abroad have shown that cooperative learning has changed the one-way interpersonal communication model in traditional classroom education, establishing a positive and democratic relationship between students and teachers. Besides, cooperative learning is effective in stimulating students' learning motivation, improving students' academic performance, cultivating teamwork spirit, and promoting students' critical thinking. During the process of communication and cooperation, students' emotional attitudes towards the classroom have changed significantly. They have become more confident in speaking and asking questions in class. At the same time, their thinking has become more active, and their abilities of business negotiations, job interviews and other business skills have also been improved by all kinds of group activities in the process of cooperative learning.

However, through Business English teaching practices and observations in recent years, the author finds that there are still some problems in the application of cooperative learning in Business English, especially when referring to classroom setting, teachers' roles in class, students' cooperative awareness and skills, and teaching assessment, so this paper tries to analyze these problems and propose related solutions to eventually improve the quality of Business English teaching.

\section{Definition AND BAsic Elements of COOPERATIVE LEARning}

Dewey (1859-1952) was an American philosopher, psychologist and pragmatist educator, as well as a reformer of traditional education and a pioneer of new education. Dewey suggested that children's personality should develop from their nature. He put forward "New Three Centers Theory": "child center (student center)" "activity center" and "experience center", which are quite different from the traditional three-centered theory of "classroom center", "teaching center" and "teacher center"(Dewey, 1902, p.117). These new three centers coincidentally conform to student-centered cooperative learning (CL), defined as an instructional method in which small groups, each with students of different levels, use a variety of learning activities to maximize their learning. With this learning model, students work together in groups to accomplish shared goals (D. W. Johnson \& R. Johnson,1998, p.89). In other words, cooperative learning is a teaching method where students of mixed levels of ability are arranged into groups and rewarded according to the group's success, rather than the success of an individual member(C V Satyaprakasha,2014, P.1100). Teaching practices at home and abroad show that cooperative learning is a creative and effective teaching strategy.

Meanwhile, the Johnson Brothers of Cooperative Learning Center at University of Minnesota proposed the five-factor theory which was unanimously accepted by the academic community. They believed that there were five basic elements of CL, which were positive interdependence, face-to face positive interaction, individual and group accountability, interpersonal and small group skills, group processing. The combination of these five elements in the group situation 
learning can effectively promote achieving the goal of CL. Actually, these five elements make CL different from other forms of group learning.

\section{The NeCESSITY OF COOPERATIVE LEARNING FOR BUSINESS ENGLISH TEACHING}

As we mentioned in the introduction part, Business English is composite and interdisciplinary, so its teaching objectives, teaching contents and teaching methods, to some degree, are different from those of traditional English. In addition to English, intercultural communication skills and business practice skills are also indispensable to Business English learners. Therefore, students majoring in Business English require extra collaboration and practice to offer them more chances to contact with each other in English, get more cross-cultural communication skills, as well as business skills. However, understanding and remembering abstract business theory and knowledge are difficult and boring. Especially, in some cases, information provided by the teachers is quite technical, so the learners try to paraphrase it to something which is appropriate to their own comprehension. Face-to-face group cooperation of cooperative learning can make Business English learners less nervous, more willing to participate, and provide them with rich opportunities to communicate in a language they can understand. Their willingness to express themselves in the target language optimizes their language skills, and if students are allowed to cooperate and analyze some business situations together through group activities, they can vividly learn the business knowledge and skills contained in these situations(Gu, 2020,pp.123-124).

Besides, in reality, most teachers know "cooperative learning produces high language proficiency in students" (Han, 2014, p.948), but most of them have never linked cooperative learning with the moral growth of students, nor have they thought that their lectures would dampen students' creativity and critical thinking, both of which are especially important for Business English learners who will engage themselves in international business. Actually, Business English learners really need to develop a critical and democratic thinking, because they have to communicate with trade partners from different countries. What's more, foreign trade is always sophisticated and changeable. By encouraging respect for differences, love, trust and appropriate compromise, group-based learning can provide good opportunities to develop such critical and democratic thinking. Meanwhile, peers interactions and modeling can promote students' self-esteem, social skills and emotional maturity needed by international business, which is also a process that requires cross-cultural communication to remove obstacles among traders and establish long-term relationships with their partners. So CL is not only a form of class dynamism, but also a way to build life-long interactions and communicative competences to deal with complicated and challenging business situations(Gu, 2020,pp.122-123). Finally, cooperation experiences can make learners more confident in their own abilities and develop their teamwork spirit, which is also essential in international business. All in all, because of the unique nature of Business English, cooperative learning is necessary for Business English.

\section{Problems of Cooperative Learning in Business English TeAChing}

\section{A. Inappropriate Classroom Setting}

Cooperative learning requires collaboration among group members to complete common learning tasks face to face. Rows of fixed desks and chairs in Chinese classrooms are no longer suitable for the new student-centered teaching model. The author even teaches Business English classes in English language labs since most classes of Foreign Language School are offered there at the author's university. Not only fixed desks and chairs, but also the computers on those tables, greatly undermine the interaction among learners. Here an example is used to illustrate the relationship between interaction and the arrangement of desks and chairs. The author's son has been studying in another city since the first grade of primary school, so the author has to take the train to go to the city to take care of him every weekend for almost nine consecutive years since the son is now a ninth-grade student of school. There are two kinds of trains the author could choose to take. One is the ordinary train, while the other is the high-speed train. The author found an interesting phenomenon is that the passengers on the high-speed train usually do not chat with each other. Instead, they watch videos or sleep on their own, since their seats do not allow them to sit face to face, but many passengers on the ordinary train will talk to each other, because they sit face to face. Therefore, the fixed desks and chairs of traditional classroom setting do affect students' interaction and collaboration,

\section{B. Unsuccessful Transformation of Teachers' Roles in Classroom.}

Cooperative learning requires teachers to transform themselves from the "leader" of the classroom to the "facilitator" or "guide" of the classroom. However, firstly, because the teaching tasks assigned by some schools are too heavy and the class hours are being compressed, teachers have to spend a lot of classroom time explaining language points, business knowledge and intercultural communication skills. In this situation, they have to be the leader, instead of the facilitator or guide in the classroom.

Secondly, although cooperative learning has been widely used in teaching in recent years, most teachers have not systematically studied this new teaching model. So many teachers lack a comprehensive understanding of cooperative learning theory, which will result in their unsuccessful role change, making cooperative learning superficial. For instance, after arranging the discussion tasks for students, some teachers either stood on the podium, watching casually, or patrolled among the students who seemingly study and discuss. They become bystanders who fail to effectively supervise and 
guide cooperative learning. On the surface, students are in a dominant position in the class, but the teacher is not clear at all about what the students are discussing, whether the topic is relevant, and whether each student is seriously involved. In their views, cooperative learning is simply a change in the way discussions are made and a change in student seating. These misunderstandings about cooperative learning would also result in the unsuccessful transformation of teachers' roles.

Thirdly, when Business English teachers do not have sufficient professional knowledge to guide cooperative learning, they would be reluctant to become "facilitator" or "guide" of the classroom. As mentioned above, in China, although Business English majors have been opened in many universities for many years, the number of Business English teachers is still very scarce. Most of the existing Business English teachers are transformed from other majors (such as translation, education, etc.). They have good English competence, and they can also get some basic business knowledge required for Business English teaching through their self-study, but most of them lack the training opportunities and practical experience to connect themselves with Business English in real situations(Gu, 2020,p.122). However, when students become the center of the learning process, their questions in the classroom are likely to exceed the teacher's preparation and expectations. As a result, the teachers would be very embarrassed if they cannot answer the questions on the spot, so they are still willing to be the leader of the classroom to avoid this.

\section{Unreasonable Formation of the Group}

An important feature of cooperative learning is that students will be divided into groups, a group being taken as the basic unit in the classroom. Groups are generally composed of students with different levels of learning ability. Each member is responsible for completing group tasks, and the group members share learning results and are truly interdependent. In reality, because of classroom management, teachers in China often do not allow students to leave their seats, so students are always randomly divided into groups in class according to their seats which are near to each other. On the one hand, the group members may not vary in interests or learning abilities, so they are unlikely to learn from each other or promote their critical thinking. One the other hand, the overall level between groups is imbalanced. A group with strong learning abilities will lose its competitive motivation because there are no competitors, while a group with weak learning abilities will remain silent or not cooperate in groups at all because of lack of self-confidence. As a result, the motivation and enthusiasm of students are reduced by unreasonable formation of the group.

\section{The Changed Cognition, Behavior and Personality of the New Generation}

\section{Poor Autonomy in Learning Prevents Classroom Activities}

Since China implemented the family planning policy in the 1980s, most families have only one child. These children are different in cognition, behavior, and personality from those of multiple-child families. Most parents of these children, whether urban or rural, are eager to send their only child to the college. To help parents realize this dream, teachers tend to adopt indoctrination and compulsory teaching methods, while students do nothing but study by basically doing a lot of exercises given by teachers, passively receiving knowledge. Therefore, after entering the university, for one thing, these students' motivation for study disappear when their college dream has come true; for another, their ability to learn independently is quite poor when they are no longer supervised by middle school teachers and their parents. They are unwilling to spend time preparing knowledge for group tasks before class. However, the important part of cooperative learning is all kinds of group activities in the classroom. In order to have better discussion and communication, students need to prepare relevant materials on their own before class. Thus, during group tasks, students who are poorly prepared before class are silent or inactive. This greatly reduces the participation of those students in class discussions or other activities, of course, the depth and breadth of class discussions are difficult to guarantee.

2. Lack of Cooperative Awareness and Skills

Cooperative awareness refers to the individual's cognition and emotion of common actions and rules of behavior, and it is an important basis for cooperative behavior, while cooperative skills refers to the ability to express, listen, find and ask questions, accept and retain opinions, and handle interpersonal relationships. However, now most Chinese college students come from the one-child families. Unlike the students from multiple-child families, they have received too much attention from parents and grandparents in their growth. As the center in the family, they think less about the feelings of others, and get used to doing tasks by themselves. Therefore, in the group learning process, they only care about expressing their own views, and are unwilling to listen to or accept the opinions of their partners. When there is disagreement during the process of completing the group task, the group members are more likely to blame each other.

\section{E. Imperfect Teaching Assessment System}

Maslow's Hierarchy of Needs indicates that people have five levels of needs, including basic physiological needs, safety needs, social needs, esteem needs and self-actualization needs. Only when students meet the needs of self-actualization or self-fulfillment and have a sense of accomplishment will they engage themselves in a new round of cooperative learning.

Assessment refers to evaluating the value of a certain thing with certain standards, whether it is good or bad, whether it meets the standard or not. Formative assessment is a dynamic evaluation of students' performance in the daily learning process, which includes quizzes, tasks, answering questions or participating in discussions in class and via teacher observation. Summative assessment is the other main type of assessment which evaluates achievements students have 
made at a stage. This kind of assessment is usually done at the end of the quarter and mid-year, and is generally used as the final cumulative exam.

At present, students' performances in Business English courses are mainly based on the middle or final examinations, one of summative assessments ending with an exact grade, because many student-centered classroom activities are more difficult to assess. Thus, teachers usually fail to give feedback to student group activities in the class, making it difficult for students to obtain a sense of accomplishment from their own performance. In fact, many students will observe the teacher's reaction at the key point of the discussion. They want to know what the teacher thinks of their speech? Especially, when students have a certain point of view during the discussion, such as expressing their own opinions and innovative thinking, if the teacher can give corresponding encouragement and evaluation in time, the student's self-actualization needs will be more likely to be met, which will in turn stimulate their interest and enthusiasm for continued discussion. Otherwise, they will be discouraged in the following tasks.

\section{Solutions to PROBlems OF COOPERATIVE LEARNING IN BUSINESS ENGLiSH}

\section{A. Improve Classroom Setting}

As a visiting scholar in the United States in 2015, I was impressed by the design of the desks and chairs in the classrooms of the university where I studied. The desks and chairs in their classrooms can be moved freely and combined into different shapes to meet the needs of various activities which will be carried out in class. For example, the desks can be combined in the form of enclosures for interviews or meetings; a round table can be also formed for group discussions with these desks. However, in most traditional Chinese university classrooms, not only are the desks and chairs fixed on the floor, but their shapes are always rectangular. Such a setting is not suitable to students' diversified group activities of cooperative learning. Therefore, desks and chairs in university classrooms should be rearranged to cooperate with this new teaching model, cooperative learning, to better serve the various group activities.

\section{B. Successful Role Change of the Teachers}

Here we can make a comparison between CL and traditional lecturing in terms of teachers' role. As the authority of traditional teaching, teachers provide students with social and language knowledge and control all communication channels. Instead, in cooperative learning, teachers become knowledge facilitators who are responsible for providing help and intervention to develop students' humanities, language abilities and business skills, which will prepare students for powerful social contributions to become responsible and democratic citizens. In short, " the teachers are no longer the authoritarians who control students' learning behavior but perceived as knowledge promoters; students are no longer passive recipients of knowledge and skills but active discoverers and constructors of knowledge"(Han, 2014, p.949). Indeed, for Business English learners, the most important thing is not how much knowledge they can learn from their teachers, but how they can effectively use the knowledge they have learned to communicate and cooperate with their partners and competitors. Don Snow also points out: "whether or not students succeed in learning a language depends more on their own efforts than on the teacher's and that a good program of instruction therefore needs to be student centered instead of teacher centered" (Snow,2007,p.20). Actually, the transformation of students' learning model will be undoubtedly realized through the change of teachers' role. Teachers should no longer regard themselves as authority in the classroom. Only when they correct their thoughts, will they adopt the proper teaching model in the teaching process.

On the other hand, now most Business English teachers in China are transformed from other majors and do not have enough business professional knowledge and skills. On the contrary, in the Internet age, students have access to all kinds of information and knowledge. To ensure the effective guidance and regulation in the cooperative learning, teachers should improve their business professional knowledge and skills through self-study, continuous learning, and even working in foreign trade companies for a period of time.

In a word, both teachers and students should change their roles and share the education responsibility. Teachers are no longer the only ones who own and provide knowledge, but become the ones who organize and guide classroom. Students are no longer the passive knowledge receivers who mechanically use what they learned in the whole process of knowledge relay, but take different roles as participants, mediators, even group leaders.

\section{Reasonable Group Formation}

Because cooperative learning takes groups as the basic unit and cooperative activities among group members as the main body, reasonable grouping plays a vital role in the learning process. Teachers must provide effective guidance to grouping which should be based on the principle of "heterogeneous in the same group" and " homogeneous out of group". "Heterogeneous in the same group" refers to grouping students with different learning abilities into the same group. The best group size is about four people, including one top student, two average students and one poor student. Group members' differences in thinking, cognitive structure, language proficiency and life experience can make them have different views on the same problem, and then propose different solutions, thus helping them develop critical thinking. The so-called "homogeneous out of group" refers to the equivalent comprehensive ability between groups, thus helping to promote fair competition between different groups. So, at the beginning of the course, teachers are better to divide students into groups based on the previous examinations or performances in classroom with the principle of "heterogeneous in the same group" and "homogeneous out of group". The same group of courses may last 4-6 weeks, then 
the change could be made according to students' performance during this period. Of course, this requires teachers to do a lot of preparation and investigation before class to understand the learning ability, personality, hobbies and life experiences of each group member.

\section{Improve Students'Autonomous Learning Ability and Cooperative Awareness and Skills}

1. Improve Students' Autonomous Learning Ability

Henri Holec pointed out in his work called Autonomy and Foreign Language Learning that "The autonomous language learner takes responsibility for the totality of his learning situation. He does this by determining his own objectives, defining the contents to be learned and the progression of the course, selecting methods and techniques to be used, monitoring this procedure, and evaluating what he has acquired."(Henri,1981).Because the time for cooperative learning in class is limited, to maximize the effect of CL, students need to be fully prepared before class, independently learning things related to the group activities to be carried out in class in advance. The following ways are suggested to promote students' autonomous learning ability.

Firstly, arouse students' learning motivation. Motivation is the essential feature of autonomous learning which is based on the learners' inner desire for study. Once learners are interested in learning, they will be eager and love to learn than ever before. Meanwhile, they will actively participate in learning, thereby greatly improving their learning efficiency. If learners treat learning as a lifelong career, then learning is no longer a task that must be completed at a certain stage, but a booster for people's continuous growth and progress (Wang, 2020, p.97). Only in this way, learning is no longer a process of passive acceptance, but a process in which learners actively participate. Or we can say, only when the learner regards learning as no longer merely a tool or means for pursuing utilitarianism, the learner will have greater autonomy in learning and their motivation to learn will last.

Secondly, ensure student-centered teaching approach in class. Student-centered teaching approach will encourage students' autonomous learning, for students have to assume the responsibility for their own learning without the control of their teachers. For instance, during the teaching process, teachers could ask students some questions instead of rushing to give answers or explanations, so as to enhance the students' ability to reflect on what they learn. Through democratic interaction between teachers and students under cooperative learning model, a harmonious teacher-student relationship could be established to promote the learner's subjectivity, initiative and consciousness in the learning process, thereby improving the students' self-control, perseverance, autonomy, eventually helpful to students' insistence on self-learning.

Thirdly, cultivate learners' ability to question, criticize and think independently. The learner's ability to think independently plays an important role in the learner's self-consciousness and subjectivity in the learning process, while by criticizing and asking more questions on what they learn, learners are no longer passive recipients of knowledge, instead, knowledge itself will become a motivating force for learners to further study, and ultimately improve their autonomous learning ability.

2. Improve Students' Cooperative Awareness and Skills

Undoubtedly, cooperative awareness and skills are essential to the success or effectiveness of cooperative learning which is based on group activities. Group members are all different in terms of academic performance, learning attitude, individual character and growth environment. Therefore, in the process of cooperative learning, group members must trust each other, respect the differences between each other, and cooperate in good faith, while in the process of guiding cooperative learning, teachers should also consciously create opportunities for students to cooperate with each other to develop their cooperative awareness, helping students establish a sense of collective honor and individual responsibility. In the end, make students comprehend that only by learning to cooperate can they succeed in future studies and work.

Cooperative skills refer to the ability to express, listen, find and ask questions, accept and retain opinions, and handle interpersonal relationships. Students should not only be able to express their opinions and answer questions, instead, they should also learn to accept the opinions of others, find and ask questions, and appreciate others. Only with these relevant cooperative skills can the effectiveness of Business English cooperative learning be greatly improved.

\section{E. Improve the Teaching Assessment System}

Scientific, fair, reasonable and timely assessments have an important impact on the success of cooperative learning, because it plays a guiding role in cooperative learning by directly reflecting the responsibilities and performance of individuals and groups. Students' learning enthusiasm and motivation are also greatly affected by the evaluation methods and results. Generally speaking, formative assessment of the learning process and summative assessment of the learning outcomes are often adopted in evaluating the students' learning. However, in the writer's opinion, the cooperative learning should focus on the formative assessment which could timely and regularly give feedback to students by evaluating the learning effect, monitoring the group activities and detecting the errors of learning process in time. On the other hand, the teachers could also improve and adjust their classroom teaching based on the feedback information in a timely and active manner, eventually providing relevant and proper guidance to the students. Formative assessment includes group self-evaluation, one of the five basic elements of cooperative learning, mutual evaluation between groups and teacher evaluation. After the group activity, first of all, the group members should make a self-assessment on whether the group has reached the agreed goals, whether the group task has been successfully completed, and then carry out mutual evaluation between groups to find merits and problems of other groups to learn from each other. Finally, the teacher ought to conduct a comprehensive and objective evaluation of each group performance according to an evaluation 
criterion, giving the groups different grades, summing up successful experiences, and pointing out the problems, to make cooperative learning more effective by maintaining the enthusiasm and vitality of the group members. Of course, the formative evaluation should be supplemented by the summative evaluation, which can reflect the students' academic performance at the end of a stage. The evaluation system combining formative evaluation and summative evaluation could comprehensively and objectively evaluate students' attitudes, emotions, and knowledge acquisition in the process of cooperative learning, and finally guide students to reflect on their own learning and keep their learning enthusiasm.

\section{CONCLUSION}

As a branch of ESP (English for Special Purpose), Business English has a complex nature. Firstly, it is a special communication system with a combination of business, English language and cross-cultural communication. Secondly, Business English is a pragmatic major which is practically oriented and closely related to the profession. So it is a comprehensive practical course with a tight integration of theory and practice. Fortunately, cooperative learning allows Business English learners to learn the knowledge and skills they need from all kinds of group activities. With this assistance, we and our students can come to enjoy and benefit from cooperation in the classroom and beyond (Sapon,1999). In other words, cooperative learning is an effective teaching model to cultivate students' business practice ability, language competence and cross-cultural communication ability. In addition, successful cooperative learning is conductive to developing students' critical and democratic thinking, autonomous learning and cooperation skills, which are highly valued by their future employers and corporations.

However, the research and practice of cooperative learning in China is still in the exploratory stage. Especially, there are many problems that arise in the process of applying this teaching model in Business English. In concrete, the traditional classroom setting is no longer suitable and needs to be improved to better serve the various group activities of Business English learners. Secondly, the reasonable group formation, instead of the random one, could help to develop critical thinking of group members and promote fair competitions between groups. Thirdly, only a perfect assessment system will guarantee motivation and enthusiasm of Business English learners for a long time. What's more, teachers are supposed to change their roles from leaders to facilitators in classroom to keep the student-centered principle of CL. Last but not the least, students are also expected to improve their autonomous learning ability, cooperative awareness and skills to ensure the effectiveness or success of CL in Business English. Identifying the problems of cooperative learning in Business English and proposing relevant solutions will undoubtedly improve the teaching quality of Business English, and ultimately help Business English learners become qualified cross-cultural business practitioners.

\section{ACKNOWLEDGEMENTS}

This paper is supported by Sichuan University of Arts and Science in the name of "Problems and Countermeasures of Cooperative Learning in Business Teaching" (Grant No. 2019XKQ004Y)

\section{REFERENCES}

[1] C V Satyaprakasha. (2014). Research Studies on Effect of Cooperative Learning on Children's Learning Preferences. International Journal of Informative \& Futuristic Research, Vol. 2, 1100.

[2] Dewey, J. (1902). The child and the curriculum. Chicago, IL: University of Chicago Press, 117.

[3] Don, Snow. (2007). From Language Learner to Language Teacher. Alexandria, VA: Teachers of English to Speakers of Other Languages, Inc, 20.

[4] D.W.Johnson \& R.Johnson. (1998). Learning and together and alone: Cooperative, competitive and individualistic learning. London: Pearson, 89.

[5] Juan Gu. (2020). On the Necessity of Cooperative Learning forBusiness English Learning. Journal of Language Teaching and Research, Vol.1, pp.122-126

[6] Haiyan Han. (2014). Transforming EFL classes from lecturing to cooperative learning. Journal of Language Teaching and Research, Vol. 5, No.4, pp.948-949.

[7] Henri Holec.(1981). Autonomy and Foreign Language Learning. Cambridge: Janus Book Publishing.

[8] Sapon-Shevin, M. (1999). Because we can change the world: A practical guide to building cooperative, inclusive classroom communities. Boston: Allyn \& Bacon.

[9] Wang Jiayin.(2020). Research on College Students' Autonomous Learning based on the Concept of lifelong learning. Heilongjiang Researches on Higher Education, Vol. 1, No.4, 97-99.

[10] Zhu Wenzhong.(2010). Business English Teaching Mode: Its Theoretical Evolution, Features and Performance, Journal of Guangdong University of Foreign Studies, Vol.21,pp.23-27.

Juan Gu was born in Sichuan, China in 1976. She received her MS degree in Foreign Linguistics and Applied Linguistics from Chongqing Normal University, China in 2012.

She is currently a lecturer in the School of Foreign Languages, Sichuan University of Arts and Science, Sichuan. Her interests include second language teaching and acquisition, Business English and translation. 